\title{
Management \& Law: FLSA Regulations And Compensation Policies - Their Legal Exposure And Business Impact
}

Ruth Torres, Keller Graduate School of Management, USA Robert C. Preziosi, Nova Southeastern University, USA

\begin{abstract}
This paper will review FLSA regulations and how this outdated law is applied to the current day workforce and the relationship between management decisions in light of FLSA regulations, their impact on compensation systems and the business resulting in legal exposure and associated costs as well as business impact. This paper also sets forth preventative measures to avoid and/or or correct these challenges via policies and systems.
\end{abstract}

Keywords: Department of Labor (DOL), FLSA Regulation violations, Wage and Hour Division (WHD), Regulation 541, Compensation, legal and business impact, exempt classification, Independent Contractor

\section{INTRODUCTION}

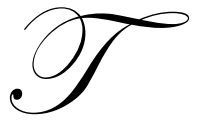

he Fair Labor Standards Act (FLSA) of 1938 established wage and hour regulations, such as a minimum wage and the New Deal statute which mandated overtime pay for hourly workers. The objectives of these regulations were to promote higher levels of employment while protecting against the abuse of low-income workers and rewarding workers for their long hours. Regulation Part 541 defines a series of exemptions from overtime payment based on the type of work an employee performs, such as executives, administrative, professionals, outside salespeople and computer employees. However, the clear distinctions of the 1930's Depression-era laws based upon defined professional and production classes have been significantly diminished in the modern workplace due to technology and use of defined and standardized processes. "Cases involving wage and hour claims accusing employers of failing to pay overtime more than doubled in federal courts from 2001 to 2006" (Pollack). There is increased attention from attorneys, targeted industries, the department of labor and according to Robin S. Conrad, head of the litigation arm of the U.S. Chamber of Commerce, "Everybody's talking about it". (Orey, 2007)

\section{DISCUSSION}

As the pressure for business performance and competition continues to increase, compounded by increased taxes, insurance, benefits and legal compliance costs, organizations typically look to reduce payroll (which is often the greatest overhead cost after technology) in one form or another such as layoffs or reduction of force, combining roles, etc., which are legal and normal business practices. However, these circumstances have also resulted in some management decisions that reduce costs short-term but have long-term negative affects and risk exposure via the violation of FLSA regulations.

For example, the following positions are challenging the exemption status for overtime payment:

Sales Representatives: Cases have been filed against every major drug manufacturer regarding the legal classification of drug company sales representatives based on the fact their conversations are tightly scripted, void of the employee's discretion, and their role is to influence physicians' prescription writing, not to directly sell products or services. (Orey, 2007) 
Mortgage brokers, loan processors and underwriters utilize scripts in defined assembly line processes; thus, challenging eligibility for overtime exemption. A number of claims against brokerage firms challenging exemption status are based on the fact that brokers are paid entirely on commission not a salary. In addition, attorney Mark Theirman has been successful in obtaining settlements for claims based on broker deductions for trading errors and sales assistant salaries, long time industry standards, under various state and federal wage laws. (Touryalai, 2006) Another issue with the exempt classification of brokers is that firms are wary of giving fiuciary control over client assets because it could expose them to greater liability and to additional regulation as investment advisors. (Washington Post, 2006)

Degreed Professionals: A degreed professional worker who exercises judgment is exempt. However, if the worker simply gathers data, enters data and follows specific defined processes, whether they are licensed or not, does not qualify them for professional status. (Orey, 2007)

IT Help Desk Workers and Programmers: Programmers are applying technical skills and rarely have any discretion. The decisions are made for them. Therefore, few programmers make decisions based on multiple options and actually qualify for exemption status. Regardless of title, IT workers performing help desk functions do not qualify for exemption per Tammy McCutchen, former head of DOL's wage and Hour Division, who helped craft the 2004 changes to overtime regulations. (Triplett, 2007)

Retail Managers: Companies classify them as executives however; they spend more time serving, performing manual labor activities than supervising others. Starbucks settled a case in California where state law requires at least $50 \%$ of the "executive" classified workers time to be spent actually managing. (Orey, 2007)However, Starbucks successfully defended the same claim in Texas under federal rules which are more flexible in the absence of applicable state laws.

There are increasing FLSA violations, such as:

I. Mis-classification of an employee as an "Independent Contractor". As an independent contractor, workers are considered self-employed. Therefore, there is generally no obligation to withhold income taxes, withhold and pay contributions to Social Security and Medicare taxes, pay unemployment insurance, or even provide benefits or comply with FMLA regulations (i.e. overtime). There is also no requirement to complete an I-9 to ensure the legal right to work (which is a significantly growing issue due to changing immigration laws and policies). In addition, there are no employee rights as enforced under various laws such as Title VII which prohibits employment based discrimination. The relative freedom from these administrative and legal requirements makes the Independent Contractor classification very tempting for employers. However, the mis-classification of an employee as an Independent Contractor can result in liability for all applicable taxes, rights and benefits for that worker, including retro or back payments and a hefty penalty.

Who is an Independent Contractor (IC)? The IRS test is detailed in Publication 15-A, Employer's Supplemental Tax Guide. The main components are:

1. The amount of control and independent judgment the worker has. A general rule is that you, the payer, have the right to control or direct only the result of the work done by an independent contractor, and not the means and methods of accomplishing the result. (Internal Revenue Service)Does the business determine the rate of pay, hours of work, and duties performed? Or does the worker decide these factors? Does the worker decide how to perform the work and the time frame for completion, control the amount of profit they earn, etc? Do they work from their own home, or have the ability to work at a base of their choosing, set their own hours and method to complete the work? Is the work performed supervised by the employer or not, etc.?

2. The level of skill required to perform the work. Does the work require specific, specialized skills or not? For example, is the worker a skilled craftsman or degreed professional or can the work be performed without any specialized skill or education? 
3. Who provides the supplies, equipment, tools to perform the work? Is the worker provided and or required to work at the business site and or use the employers' computers, equipment, tools, etc. or does the worker use their own tools and supplies?

4. Length of time- those working as an Independent Contractor (IC) for one sole client for greater than a 6 month period of time is almost always not considered an IC unless a licensed contractor for a major and specific project lasting longer, for example a large construction project.

5. Whether or not the work is a part of the regular business of the employer.

6. What is the method of payment? Is it based on the hours worked or the work performed?

7. Whether the person is in operation of their own business, which is established by registration, certification, licensure, etc.

If the worker is required to report to work at a certain time, uses only company equipment, has their pay rate, hours and duties defined by the employer, this is an employment relationship not an Independent Contractor. Often companies require the employee to sign a contract or document which specifies their role as an Independent Contractor in order to begin work. However, this type of document does not negate the employers' responsibilities, even if the worker signed and notarized a document accepting the position as an independent contractor status since such a document does not supersede law.

Many small businesses are able to utilize this mis-classification with little or no impact. That is largely due to the worker being well compensated, not knowing the law or being afraid to bring attention to themselves by filing a claim. This particular type of violation is likely to significantly increase especially in light of focus and pressure for immigration legislation and changes in immigration policies. However, organizations should understand the legal risk along with the fines and retro costs of up to 2 years to make the employee whole for mis-classification, which usually occurs when a disgruntled worker files a discrimination or wrongful termination claim or files for unemployment.

II. The $2^{\text {nd }}$ type of FLSA violation is due to the mis-classification of the worker as an exempt employee not eligible for overtime. The threshold for this exemption as defined by FLSA Regulation 541 is a relatively low one and includes the requirement for the employee to (1) be compensated on a salary basis at a rate of not less than $\$ 455$ per week (2) customarily and regularly direct the work of two or more other employees; and (3) have the authority to hire or fire other employees. The Department of Labor, Wage and Hour Division (WHD) reports \$16 Million collected in 2007 for back wages for this type of claim compared to \$13.2 Million collected in 2006 for the relatively same number of claims. In addition, recently there has been a significant increase in the amount of litigation and, thus, attention for this type of claim, including several class action cases (listed below) that have resulted in high dollar settlements with more cases pending. However, a recent Alabama federal court made a ruling that strongly favors retailers in the exempt classification of "managers" inspite of the fact that these employees spend as little as $15 \%$ of their time actually managing others.

In Allen v. Dolgencorp Inc. the court ruled that Dollar General Store managers were properly classified as "executive" employees even though they spent approximately $85 \%$ of their time performing non-exempt duties, such as cleaning the store and working the cash register. The court went on to analyze the four "pertinent factors" that must be weighed where an allegedly exempt executive employee spends less than $50 \%$ of his or her time performing exempt management duties. The factors are discussed below.

1. The relative importance of managerial duties as compared with other types of duties. The court found that the manner in which Dollar General trained, evaluated, and compensated the store managers demonstrated that managerial duties were more important to Dollar General than the non-managerial duties that the store managers performed. (Dube, 2007)

2. The frequency with which the employee exercises discretionary powers. The court found that the store managers exercised independent discretion even though they were required to consult manuals or guidelines (i.e. plan-o-grams, merchandising programs, etc.). (Dube, 2007) 
3. The relative freedom from supervision. The court found that despite instruction from district managers, the store managers were generally the highest level of supervisory personnel in the stores on a daily basis, particularly since district managers only visited their stores approximately once per month. (Dube, 2007)

4. The relationship between the employee's salary and the wages paid other employees for the kind of nonexempt work performed by the supervisor. The court observed that the store managers earned approximately twice as much as the next highest paid employee in their store and were the only employees eligible for bonuses. According to the court, "[t]his factor clearly supports a determination that [the store managers] are exempt." (Dube, 2007)

Based on its analysis, the court held that the store managers had been properly classified as exempt executive employees under the federal FLSA and were not entitled to overtime compensation. Some other federal courts have reached the same conclusion in similar cases. For example, a federal court in Texas found Starbucks store managers to be exempt from overtime requirements even though they spent a majority of their time performing non-exempt duties, such as cleaning the store and serving customers. (Dube, 2007)

The court said that the expedited ruling was intended to assist the parties in resolving common legal issues that may affect 1,603 other individual cases pending before the court. (Dube, 2007) No doubt this ruling will affect the 1,603 similarly based individual cases against Dollar General as well as many others in the US Federal Courts $11^{\text {th }}$ Circuit which includes Alabama, Georgia and Florida. Thus, in this one decision the courts significantly reduced their workload. However, it should be noted that this case occurred in Alabama which has not enacted a state law regarding exempt classifications for employees. Other states (for example, California) have enacted regulations regarding exempt classifications that, at times, are more challenging for employers. Employers should consult both federal and state law when classifying employees as exempt from overtime requirements. (Dube, 2007)

III. Another type of FLSA violation is for non-payment or mis-calculation of overtime payment due to off-theclock work, exclusion of bonuses or other payments for work performed in the calculation of overtime. Off the clock examples include not being paid for time while the business location is opened or closed and the system is non-operational to record time, employees forced to work during lunch breaks or other work without recording work time. Mis-calculation of overtime occurs when bonuses or other work or performance based payments such as workshift, safety or productivity differentials are distributed and not included in the overtime calculation.

Regardless of the type of claim, the main fuel is the worker becoming upset with their supervisor or the organization, often for an employee relations issue. These claims are challenging long standing practices and business norms yet most workers don't realize the overtime compensation they are entitled to under federal law because of their elevated titles and the accompanying perception of prestige. In fact, most salaried workers view the long hours, required attendance at meetings, email and other communications outside of the workplace and normal work times, etc. as an industry standard and representative of their importance to the organization, for almost every industry. However, this viewpoint from a position of pride is quickly changing when a disgruntled current or former employee reaches their maximum tolerance point as a result of the correlation of work / life impact, compensation and some employee related internal dispute and seeks retribution.

The legal impact and cost for these claims can be significant. The Department of Labor, Wage and Hour Division (WHD) enforces Federal minimum wage, overtime pay, recordkeeping, and child labor requirements of the Fair Labor Standards Act. WHD also enforces a number of federal laws including employment standards and worker protections as provided in several immigration related statutes. Additionally, WHD administers and enforces the prevailing wage requirements of the Davis Bacon Act and the Service Contract Act and other statutes applicable to Federal contracts.

The DOL has enforced these laws requiring employers pay back wages and imposing hefty fines. Willful violations of withholding of overtime results in an automatic doubling of amounts due. (Touryalai, 2006) The DOL has used virtually every enforcement tool at its disposal - directed cases, complaint cases, conciliations, withholding of funds on federal contracts, debarments, litigation, and referral to criminal prosecutors - to ensure compliance with the labor standards laws within its jurisdiction. 
DOL, Wage and Hour Division (WHD) records indicate the collection of a record \$220 million in back wages for over 341,000 employees in fiscal year 2007.

- $\quad$ The Employment Standards Administration's Wage and Hour Division (WHD) recovered more than \$220 million in back wages for over 341,000 employees in fiscal year 2007. (DOL, 2008)

- WHD concluded one investigation in which the Division collected over $\$ 31.9$ million in back wages for approximately 79,350 employees. WHD back wage collections and the number of workers receiving back wages remains high even if this record-breaking case is excluded from the year-end totals. (DOL, 2008)

Back wage collections exceeded the record levels collected in fiscal year 2003 by 3.8 percent. The agency concluded 30,467 compliance actions and assessed over $\$ 10.3$ million in civil money penalties. (The concluded case numbers represent all investigations and conciliations for which the Department has completed work during the fiscal year. Cases are generally concluded when back wages are collected and distributed, civil money penalties are paid, no violations are disclosed, or no further action is appropriate). (DOL, 2008)

Table 1: DOL, WHD Enforcement Statistics, 2003-2007

\begin{tabular}{|l|c|c|c|c|c|}
\hline & FY2003 & FY2004 & FY 2005 & FY 2006 & FY 2007 \\
\hline Back Wages Collected & $\$ 212,537,554$ & $\$ 196,664,146$ & $\$ 166,005,014$ & $\$ 171,955,533$ & $\$ 220,613,703$ \\
\hline Employees Receiving Back Wages & 342,358 & 288,296 & 241,379 & 246,874 & 341,624 \\
\hline Complaints Registered & 31,123 & 31,786 & 30,375 & 26,256 & 24,950 \\
\hline Concluded Cases & 39,425 & 37,842 & 34,858 & 31,987 & 30,467 \\
\hline
\end{tabular}

- The number of registered complaints declined for the third year, reflecting an agency emphasis on complaint intake strategies that screen incoming calls and correspondence to ensure that the issue is properly within WHD's enforcement jurisdiction. These complaint screening strategies contributed, in some part, to a decline in the percent of WHD complaint investigations that find no violation of WHD laws. (DOL, 2008) However, this is evidence of workers seeking venues of retribution for actions they feel are unfair .

- Over 311,000 employees received fair labor standards act back wages. In fiscal year 2007, more than 311,000 employees received a total of $\$ 180.7$ million in minimum wage and overtime back wages as a result of Fair Labor Standards Act (FLSA) violations. WHD collected over \$163 million in back wages for FLSA overtime violations and more than $\$ 17$ million for FLSA minimum wage violations. Back wages for overtime violations represented roughly 90 percent of all FLSA back wages collected, and the number of employees receiving overtime back wages represented about 95 percent of all employees due FLSA back wages. WHD also assessed employers \$3.9 million in FLSA civil money penalties. (DOL, 2008)

Table 2: DOL, WHD Back Wages Statistics, Minimum Wage \& Overtime

\begin{tabular}{|l|c|c|c|c|c|}
\hline & Cases & $\begin{array}{c}\text { Back Wages } \\
\text { Collected }\end{array}$ & $\begin{array}{c}\text { Percent of FLSA } \\
\text { Back Wages }\end{array}$ & $\begin{array}{c}\text { Employees Receiving } \\
\text { Back Wages }\end{array}$ & $\begin{array}{c}\text { Percent of Employees } \\
\text { Receiving FLSA Back Wages }\end{array}$ \\
\hline Minimum Wage & 11,128 & $\$ 17,287,277$ & $10 \%$ & 47,495 & $15 \%$ \\
\hline Overtime & 10,854 & $\$ 163,391,549$ & $90 \%$ & 295,129 & $95 \%$ \\
\hline
\end{tabular}

- $\quad$ Compliance with the part 541 overtime security regulations remains steady. Of the $\$ 180.7$ million in FLSA back wages collected, nearly $\$ 16$ million was collected for approximately 12,000 employees as a result of violations of the Overtime Security regulations (29 C.F.R. Part 541). This compares to $\$ 13.2$ million collected for approximately 12,000 employees in fiscal year 2006. The violation most frequently cited was one in which the employee's primary duty was not "the performance of office or non-manual work directly related to the management or general business operations of the employer or the employer's 
customers." This violation of the administrative duty test was cited in 296 cases and affected approximately 2,500 employees. Back wages resulting from determinations that management was not an employee's primary duty were in excess of $\$ 4.5$ million and represent the greatest dollar amount collected for a Part 541 violation. (DOL, 2008)

- Back wages collected for workers in low-wage industries increased. WHD continues to pursue compliance in low-wage industries that employ young and immigrant workers. In fiscal year 2007, the agency collected over $\$ 52.7$ million in back wages for approximately 86,500 workers in low-wage industries - an increase of over 33 percent of back wages collected during fiscal year 2003 for violations in the same group of low-wage industries. WHD expends nearly 40 percent of its enforcement resources on investigations in the nine low-wage industries listed below. (DOL, 2008)

Table 3: DOL, WHD Low Wage Industry Statistics by Category 2007

\begin{tabular}{|l|c|c|c|}
\hline Low-Wage Industries Statistics & Cases & Back Wages & Employees \\
\hline Agriculture & 1,667 & $\$ 3,186,854$ & 8,671 \\
\hline Day Care & 711 & $\$ 1,181,539$ & 3,191 \\
\hline Restaurants & 4,469 & $\$ 17,432,805$ & 27,661 \\
\hline Garment Manufacturing & 676 & $\$ 2,891,475$ & 3,449 \\
\hline Guard Services & 729 & $\$ 7,545,704$ & 11,584 \\
\hline Health Care & 1,431 & $\$ 9,899,417$ & 17,488 \\
\hline Hotels and Motels & 880 & $\$ 2,125,797$ & 8,246 \\
\hline Janitorial Services & 464 & $\$ 6,972,362$ & 8,420 \\
\hline Temporary Help & 355 & $\$ 1,486,728$ & 1,850 \\
\hline Total Low-Wage Industries & 11,382 & $\$ 52,722,681$ & 86,560 \\
\hline
\end{tabular}

Table 4: DOL, WHD Low Wage Industry Back Wage Statistics 2007

\begin{tabular}{|l|c|c|c|c|c|}
\hline & FY2003 & FY2004 & FY 2005 & FY 2006 & FY 2007 \\
\hline Back Wages Collected & $\$ 39,595,382$ & $\$ 43,141,911$ & $\$ 45,783,743$ & $\$ 50,566,661$ & $\$ 52,722,681$ \\
\hline Employees Receiving Back Wages & 80,772 & 84,897 & 96,511 & 86,780 & 86,560 \\
\hline Cases In Low-Wage Industries & 12,962 & 12,625 & 12,468 & 11,172 & 11,382 \\
\hline
\end{tabular}

Low-wage workers in the Gulf Coast receive over \$7 million in back wages in 2007. In fiscal year 2007, WHD opened over 400 hurricane-related cases. Since the 2005 hurricanes, WHD has opened 750 hurricane-related cases and collected nearly $\$ 4.9$ million in back wages for 9,000 workers in concluded cases. The agency has collected an additional $\$ 2.5$ million in back wages on cases not yet concluded. (DOL, 2008)

WHD continues strong child labor enforcement results for fiscal year 2007 showing a total of 4,672 minors found illegally employed, an average of 3.7 minors illegally employed per investigation. The majority of child labor violations occurred when workers under the age of 16 worked too many hours, too late at night, or too early in the morning. In total, 3,406 minors were employed in violation of the child labor hour's standards. Hazardous Occupation Order (HO) violations were found in a third of the cases with child labor violations. Violations of HO No. 12 (paper balers) were the most common type of HO violation found, followed by violations of HO No. 2 (driving). WHD assessed nearly \$4.4 million in child labor civil money penalties in fiscal year 2007. (DOL, 2008) 
Table 5: DOL, WHD Child Labor Statistics, 2003-2007

\begin{tabular}{|l|c|c|c|c|c|}
\hline \multicolumn{1}{|c|}{ Child Labor Statistics } & FY2003 & FY2004 & FY 2005 & FY 2006 & FY 2007 \\
\hline Self-Directed Child Labor Cases & 2,031 & 2,155 & 1,406 & 952 & 1,285 \\
\hline Cases With Child Labor Violations & 1,648 & 1,616 & 1,129 & 1,083 & 1,249 \\
\hline Minors Employed In Violation & 7,228 & 5,840 & 3,703 & 3,723 & 4,672 \\
\hline Minors Per Case & 4.4 & 3.6 & 3.3 & 3.4 & 3.7 \\
\hline Cases With HO Violations & 654 & 459 & 396 & 361 & 410 \\
\hline Minors Employed In Violation of HOs & 1,449 & 1,087 & 1,091 & 994 & 1,000 \\
\hline
\end{tabular}

DOL, wage and hour division has faced significant challenges in responding to the compliance situation in the Gulf Coast region, including the changing labor demographics, the large number of employees mis-designated as independent contractors, the inaccessibility to workers and worksites, and the infusion of federal assistance into the region that resulted in government contracts with multiple layers of subcontracting and blurred lines of employer accountability. As a result, the WHD has re-allocated resources to the Gulf Coast areas to investigate claims. Since January 2006, WHD has detailed additional investigators and managers to New Orleans and the Mississippi Gulf Coast on a temporary rotational basis. These rotations included over 30 different investigators - the majority of whom were bilingual - and five managers from over 20 WHD offices around the country. In addition, the agency has hired four new investigators for the New Orleans district office and two new investigators for the Gulfport field station, as well as a new assistant district director for the New Orleans district office. WHD also transferred a senior team leader to the New Orleans district office for a multi-year detail and opened a satellite office space in Kenner, Louisiana, to better serve the local Hispanic community. (DOL, 2008)

DOL, 2008 initiatives include maintaining a strong presence in the Gulf Coast region as clean-up and reconstruction activities continue. Throughout the next several years, WHD will allocate enforcement resources to the region, explore new strategies and partnerships to reach vulnerable workers, and pursue opportunities to meet any new compliance challenges that may arise along the Gulf Coast. (DOL, 2008)

In addition to this effort, WHD regions have planned regional and local initiatives for fiscal year 2008. These initiatives employ the strategies of compliance assistance, partnerships, and directed enforcement to increase compliance with the FLSA, including child labor, in low-wage industries. In support of the agency's goal to increase compliance in areas in which young workers are most likely to be injured, WHD's fiscal year 2008 child labor initiative will focus on increasing compliance with HO No. 12 (balers). WHD's fiscal year 2008 efforts to increase compliance in low-wage industries will be concentrated in those industries, such as construction, janitorial, hotel and motel, and day labor, in which the agency is most likely to find minimum wage and overtime violations as a result of employers' mis-designation of employees as independent contractors. A component of the agency's lowwage focus will include regional and district enforcement initiatives in agriculture to increase compliance with the Migrant and Seasonal Agricultural Worker Protection Act. WHD will also continue to focus on increasing compliance among prior violators through both directed and complaint investigations and to effectively manage its complaint program to increase labor standards outcomes for the greatest number of workers. (DOL, 2008)

Due to the number of claims filed and their resources, investigation may take up to 6 months or more to begin after the claim is filed according to a DOL wage and hour division investigator. Employers found to have willfully withheld overtime are automatically charged double any amount due. However, the greatest cost may not directly be imposed by the DOL but rather incurred via attorneys filing of claims under FLSA 16 (b). In fact, Mark Thierman, an attorney in Nevada has been extremely successful in leading a number of class action cases achieving very large settlements that should be sending a strong message to business and human resources leaders to scrutinize employee status classification and compensation practices. Class action settlements include:

- $\quad$ Starbucks- \$ 18 Million, Starbucks case based on California based exempt "managers" not being paid overtime in spite of over $50 \%$ of their time was spent preparing lattes and serving customers. 
- Wal-Mart- \$172 Million in California, \$ 78.5 million in Pennsylvania, \$33 Million for OT mis-calculations and approximately 80 wage and hour suits in the last 2 years.

- Hollywood Video- $\$ 7.2$ Million for workers unable to punch in and out to record all time worked due to system start-up and shut-down at opening and closing.

- $\quad$ Siebel Systems- $\$ 27.5$ million to about 800 software engineers.

- $\quad$ IBM- $\$ 65$ Million to technical and customer support workers.

- $\quad$ Merrill Lynch- $\$ 37$ Million for exempt classification on brokers (154 DLR AA-1, 3/6/06)

- $\quad$ Morgan Stanley- $\$ 42.5$ Million for exempt classification on brokers (43 DLR AA-1, 3/6/06)

- $\quad$ UBS- $\$ 89$ Million for exempt classification (28 DLR AA-1, 2/10/06).

- $\quad$ Smith Barney- $\$ 98$ Million for exempt classification (101 DLR AA-1, 5/25/06).

- $\quad$ Bank of America- $\$ 9 \mathrm{M}$ for overtime calculation for mortgage \& loan workers.

- $\quad$ Country Wide Home Loans- $\$ 30 \mathrm{M}$ for OT for call center sales associates.

- $\quad$ Bridgestone/ Firestone- $\$ 8$ Million for managers overtime.

- $\quad$ Footlocker- A class action is pending court approval.

Attorneys have specified their targets for more class action FLSA claims include:

Type of companies: Large employers of computer personnel, banks, health insurers, Stock brokerage firms, mortgage companies.

Positions: Brokers, dealers, IT workers, programmers, IT help desk workers, mortgage originators, underwriters, loan processors, retail management.

If the legal risks and monetary costs aren't enough, an organization may experience other affects of these management decisions including:

- Increased shrink or loss of product or cash- Employees that feel their wages are being stolen from them may feel entitled to recoup their losses by stealing company property.

- $\quad$ Increased turnover or loss of personnel requiring increased recruitment and training costs.

- Low or Reduced productivity of workers and managers due to internal compensation disputes, disruption to normal course of business or workers involvement in class action claims.

- $\quad$ The public relations impact hasn't been a significant issue to date. Legal actions seem to be an accepted cost of business. However, public perception could affect sales directly or indirectly as well as potential investors who do their homework.

\section{Preventions And Solutions Include:}

1. Properly classify workers. If they don't truly qualify as Independent Contractors (IC), they are employees. In classifying employees as exempt or non-exempt, focus on what the worker actually does, not their job title, income level or academic degree is the suggestion from prevailing attorney Mark Thierman. (Orey, 2007) Particular attention must be made on job description accuracy, not just what the organization wants the position incumbents to perform theoretically but what workers are actually performing in practical application. The development of job descriptions should include visual observation of the work being performed to ensure accuracy and proper classification. Job descriptions should also be reviewed and updated accordingly on a regular basis.

To properly classify workers as exempt, properly train and trust workers with the ability to analyze, use discretion, make independent judgment, manage processes, client accounts and / or other employees with applicable authority. To reduce risk and complications, exempt workers should be spending $50 \%$ or more of their time performing management duties. 
2. Alternatively, the organization may retain control over all these factors and pay associates an hourly wage with applicable overtime. When in doubt, classify as a non-exempt employee and pay for overtime worked. There are no legal repercussions or penalties for paying every worker hourly.

3. Compensate exempt workers properly, at higher levels than hourly associates taking into consideration the total number of hours being worked, including meetings and communications outside of the normal business hours and locations. Compensate sales representatives on a fee basis or a salary or a combination of salary and nondiscretionary commissions or bonuses at a minimum of $\$ 455$ per week, not solely based on a commission or a draw. Thierman suggests that brokerage firms raise salaries and continue the trend to tie pay to client's assets under management. (Washington Post, 2006)

4. Train supervisors and managers on the various aspects of FLSA, including an annual refresher course and policy adherence requirement and enforcement, to maintain proper alignment and compliance.

5. Don't pass along work related costs to employees which, deduct from their total earnings. Nickel and diming employees is another method for short-term gain for long-term loss as well as other business impacts. Although most states allow some deductions with limitations, doing so is rarely worth it in the long term.

6. Ensure HRIS payroll systems capture and correctly include all compensation distributions within overtime calculations including non-discretionary bonuses or other distributions such as shift, safety and productivity differentials, and other applicable. The regular rate includes all remuneration for employment except certain payments excluded by the Act itself. Payments which are not part of the regular rate include pay for expenses incurred on the employer's behalf, premium payments for overtime work or the true premiums paid for work on Saturdays, Sundays, and holidays, discretionary bonuses, gifts and payments in the nature of gifts on special occasions, and payments for occasional periods when no work is performed due to vacation, holidays, or illness. (U.S. Department of Labor, 2007)

Earnings may be determined on a piece-rate, salary, commission, or some other basis, but in all such cases the overtime pay due must be computed on the basis of the average hourly rate derived from such earnings. This is calculated by dividing the total pay for employment (except for the statutory exclusions noted above) in any workweek by the total number of hours actually worked. (U.S. Department of Labor, 2007)

7. Provide a mechanism to report and capture hours worked outside of the normal work location including for work related meetings, trainings, presentations, remote access to work files and email, work related phone calls or electronic communications, preparations for the workday (i.e. define route patterns or file downloads), etc. or due to the inability to utilize the location time clock. Ensure these tasks and associated time is taken into consideration for classification eligibility and applicable overtime calculation.

8. Provide internal resources for workers to report and resolve compensation and employee relations issues, providing confidential and non-retaliatory venues for reporting complaints.

9. Don't solely rely on DOL opinion letters when making management decisions since an organization is still liable for violations if the opinion is later rejected by a court since a good faith affirmative defense generally doesn't work. (See Triplett,2007)

10. Attorney Mark Thierman was asked to provide further advice for employers and responded, “ I don't counsel employers on why they should obey the law; I assume they want to comply after they understand what is expected of them." (Thierman, 2007) So, make sure you have compliance mechanisms in place and self regulate and audit on a regular basis.

11. Outsource if appropriate. Outsourcing may be the best option for small employers seeking to avoid the administrative and legal requirements associated with employees. Outsourcing could include employing workers through a PEO or employment labor agency. The costs for these services far outweigh the legal risks and costs as well as lifting the administrative burden small business are sometimes ill-equipped to handle.

12. Implement and maintain a culture that promotes a work / life balance, health and stress control. According to the Center for Work-Life Policy (CWLP), workplace policies that address the work-life challenge can benefit the lives of working parents and the lives of their children and simultaneously promote workplace retention, diversity and productivity, thereby improving the bottom line. Studies conducted by the CWLP have been published in the Harvard Business Review. (Center for Work-Life Policy, 2007) 


\section{AUTHOR INFORMATION}

Ruth Torres is a business consultant with HR Strategic Consulting based in South Florida \& an adjunct professor with Devry \& Keller Universities. She holds a Bachelors Degree in Business Administration from Dallas Baptist University \& a Masters in Management of Human Resources from Florida International University. She has worked with several Fortune organizations including Viacom, Blockbuster \& Federated Logistics. Ruth is a member of the Society of Human Resource Management, having obtained SPHR certification as well as certification as a Mediator in Florida. Ruth is currently pursuing her Juris Doctorate from Nova Southeastern University, Shepard Broad Law School.

Dr. Robert C. Preziosi is the Faculty Chair of HRM and a Professor of Management at the H. Wayne Huizenga School of Business and Entrepreneurship. He is a former Director of HR and VP of Management Development. He is on the editorial boards of Employment Relations Today, Employee Responsibilites and Rights Journal, Journal of Business Case Studies and Journal of Applied Management and Entrepreneurship. He is President of Preziosi Partners, Inc. which focuses on Leadership Development. He is the former editor of the Pfeiffer HRM Annual and is current Editor of the Pfeiffer Management Development Annual. He is the author of a new book, The Leadership Road. He is a frequent presenter at professional and academic conferences and has been a keynote presentor for businesses and government agencies.

\section{BIBLIOGRAPHY}

1. Center for Work-Life Policy. (2007, June 24). Retrieved February 5, 2008, from Wikipedia: http://en.wikipedia.org/wiki/The_Center_for_Work-Life_Policy

2. Cronin Fisk, M. (2005, September 21). BofA settles class action overtime suit. Bloomberg News .

3. DOL. (2008, January). Department of Labor, Wage and Hour Division. Retrieved January 7, 2008, from http://www.dol.gov/esa/whd/statistics/200712.htm

4. Dube, L. E. (2007, September 28). Bureau of National Affairs. Retrieved January 7, 2008, from http://emlawcenter.bna.com/pic2/em.nsf/id/BNAP-77GQDR?OpenDocument

5. $\quad$ Internal Revenue Service. (n.d.). Retrieved January 7, 2008, from http://www.irs.gov/businesses/small/article/0,,id=99921,00.html

6. Juan, E. (2006, March 3). Morgan Stanley settles overtime claims for \$ $42.5 \mathrm{mln}$. Bloomberg News .

7. Knightley, A. (2006, September 20). Dealers Sue Wynn over tips plan. Las Vegas Business Press.

8. McGeehan, P. (2005, August 10). Merrill Settles Brokers' Suit for Overtime in California. NY Times .

9. Mills, J., \& Van Voris, B. (2006, February 8). UBS to Pay \$ 89 Mln to Settle Broker Overtime Lawsuits (Updated). Bloomberg News .

10. Orey, M. (2007, October 01). Wage Wars. Business Week .

11. Pollack, W. (2007, September 24). Changing Workplace Spurs More Overtime Lawsuits. Wall Street Journal .

12. Smith, P. (2004, August 30). Wage-and-hour suits- the next hot stock tip? The Recorder, pp. 1, 7.

13. Thierman, M. (2007, October 24). Email Response . (R. Torres, Interviewer)

14. Touryalai, H. (2006, May 1). Wall Street Wage Fight. Wall Street Journal .

15. Triplett, M. R. (2007). FLSA: Wal-MArt / DOL pact may prompt more claims involving overtime calculation, attorneys say. BNA Daily Labor Report.

16. U.S. Department of Labor, E. W. (2007, November). Fact Sheet \#23: Overtime Pay Requirements of the FLSA. Retrieved February 5, 2008, from Department Of Labor: http://www.dol.gov/esa/regs/compliance/whd/whdfs23.pdf

17. Washington Post (2006, May 23). Citigroup Unit to Pay to Settle OT Claims. Washington Post.com . 